\title{
Tobacco sponsorship is no laughing matter
}

Despite intense effort by tobacco control groups during the past decade, legislation to control tobacco promotions in Canada has been limited in its effectiveness. The Tobacco Products Control Act (TPCA) was legislated in 1988 and although it banned tobacco product advertising, sponsorship remained permissible with limitations. The full name of the manufacturer was required on promotional material as opposed to a tobacco brand name. In response, all three Canadian tobacco companies hastily registered their various brands as separate corporate entities as the TPCA took effect. Imperial Tobacco Ltd, RJR-Macdonald Inc., and Rothmans, Benson \& Hedges Inc. formed "shell" companies for sponsorship purposes that matched each of their various cigarette brands. For example, Imperial Tobacco Ltd formed new corporate entities such as Player's Ltd, du Maurier Ltd, and Matinée Ltd so that it could advertise events sponsored in these brand name corporations rather than under the corporate identity of Imperial Tobacco.

Although advertisements that promoted events sponsored by tobacco companies were not permitted to display or mention cigarettes or tobacco, the graphic design, typography, logos, and colouring of such advertisements were often virtually identical to the brand name packages. Before the implementation of the TPCA, advertisements which made direct reference to tobacco products required health warnings. However, health warnings were not necessary for advertisements (point-of-sale displays, transit advertisements, billboards, magazine and newspaper advertisements, and radio and television spots) which promoted events sponsored by the tobacco "shell" companies. ${ }^{1}$ The logos of the newly formed corporate entities were also placed on non-tobacco items such as teeshirts, hats, and towels. Thus, the colours, designs, trademarks, and logos used on particular tobacco brand packages became the key mechanism of promotion under the provisions of the TPCA.

As advertising regulations became increasingly restrictive, the tobacco industry invested heavily in the sponsorship of various events. Canadian tobacco companies contributed approximately C\$10 million during 1987 towards sponsoring cultural and sports events, growing six-fold to reach $\$ 62$ million by $1995 .^{23}$

Sponsorship enables tobacco companies to associate their brands with desirable traits. For example, Export "A" Inc. began to sponsor an extreme sport series that includes risk-taking activities such as couloir skiing (down a steep, narrow chute), mountain biking, and wild water kayaking. These activities involve competitors who succeed because of their willingness to take extreme risks. Promotions for these events appeal to the viewer's desire for independence because the selected activities are all individual sports. ${ }^{4}$ The Matinée Fashion Foundation was formed in 1992 and serves as a second example. Sponsorship of fashion events allows tobacco products to be associated with models who are typically thin. Promotional messages for these events may reinforce the idea that smoking suppresses appetite and is a means of controlling body weight. Other Canadian tobacco-sponsored activities or events include golf and tennis tournaments, auto races, fireworks displays, and jazz, film, and comedy festivals.

\section{Just For Laughs comedy festival: a case study}

Now in its 16th year, the Fust For Laughs comedy festival held in Montreal is the world's largest and most renowned showcase for world-class comedy talent. ${ }^{5}$ The festival, with its annual budget of $\mathrm{C} \$ 16$ million, exemplifies

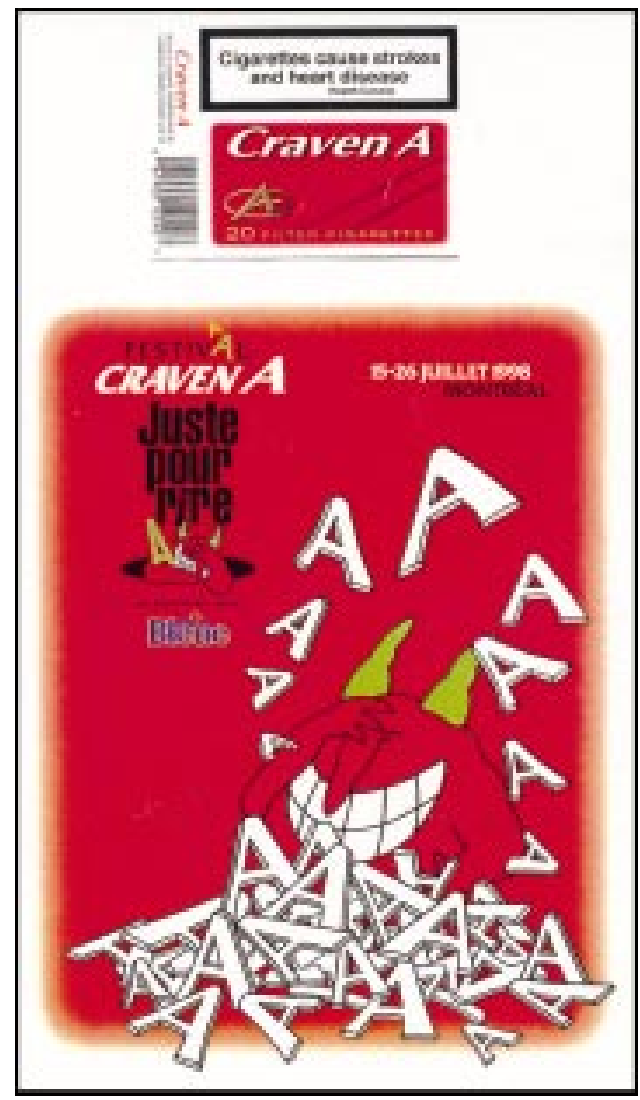

Figure 1 Cigarette package graphics (top) and advertisement graphics in the fust For Laughs comedy festival programme. 


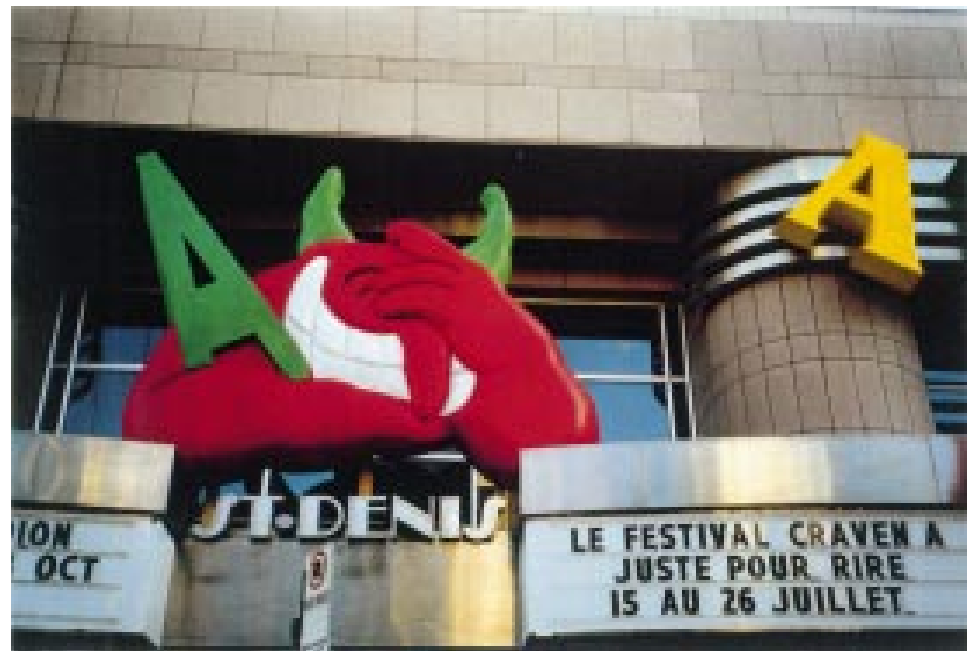

Figure 2 Théâtre St Denis, Montreal: setting for the star-studded galas.

a high-profile cultural event that has a Canadian tobacco company as the major sponsor (figure 1). ${ }^{6}$ Rothmans, Benson \& Hedges Inc., through its brand Craven $A$, is the major sponsor of the festival for the fourth consecutive year. The festival, which began in 1983 as a two-night French language comedy show, has developed into a large scale, bilingual event. The festival has been referred to as the "Cannes of Comedy" since industry executives, television producers, managers, agents, and talent scouts attend to discuss the newest trends in comedy and bid on the most promising talent. More than 1000 television, film, and comedy industry representatives attended the 1996 festival, including the casting heads of every major studio and network in Hollywood. In 1997, approximately 550 journalists were accredited with covering the festival. Artists from eleven countries gave over 1300 perform-

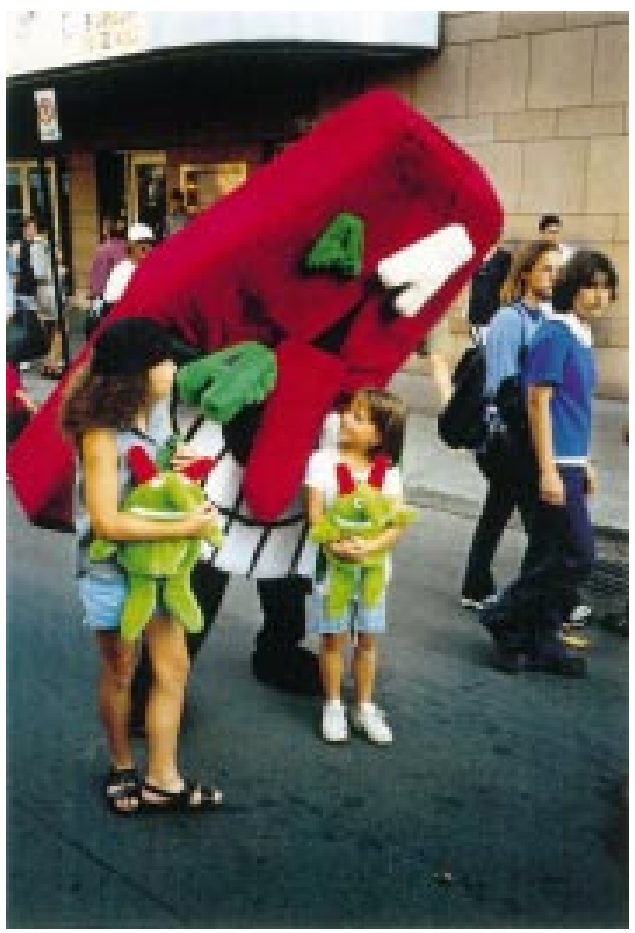

Figure 3 Craven A mascot playing with young children.

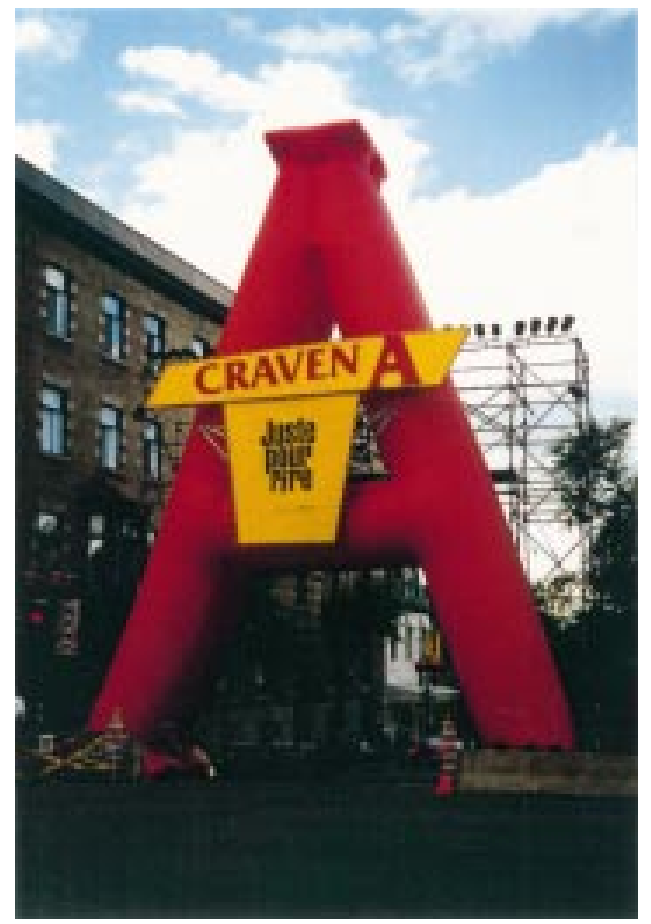

Figure 4 Craven $A$ at the entrance to the outdoor festival site.

ances to paying customers. During its 16-year history, performers at the festival have included Rowan Atkinson, Roseanne Barr, George Burns, John Candy, Jim Carrey, Kelsey Grammer, Bob Newhart, Jerry Seinfeld, Lily Tomlin, and Mary Tyler Moore. ${ }^{5}$

The 1998 Just For Laughs festival attracted a record attendance of 1.2 million people, roughly double that from the previous year. ${ }^{7}$ The star-studded galas for the 1998 event were held at Théatre St Denis and the festival mascot overlooked the entrance (figure 2). ${ }^{8}$ During 1995 more than 800 million viewers from 40 countries watched "Just For Laughs" festival highlights on television. ${ }^{9}$

Most attendees turned up for the 2000 free outdoor shows on St Denis Street, estimated to have drawn more than one million viewers. ${ }^{7}$ There was no restricted age access for these free outdoor festivities and the audience included many minors and families. Souvenir stands sold items that were appealing to children. The mascot found on the "Craven A Just For Laughs" promotions was represented on furry knapsacks, teeshirts, and postcards that featured comic book/cartoon-like sequences. The furry knapsacks were particularly popular among young children.

Mascots walked around affectionately greeting young children (figure 3). One of the "live" walking mascots appeared on nearly all of the "Craven A Just For Laughs" promotions. Although this mascot is red and associated with the name Craven A, it could be argued that it is representative of the festival itself. Indeed, this mascot existed before Craven A became the major sponsor of the event. However, the other mascot is a red " $\mathrm{A}$ ", representative of the cigarette brand Craven A. 
Roadblocks were located at major crossstreets so that traffic would not interrupt the street performances and festivities. A big red "A" was located at the primary intersection of Sherbrooke and St Denis (figure 4) and illuminated at night. There were numerous visible reminders that Craven A was the sponsor of this event. Several restaurants with outdoor patios featured tablecloths, patio umbrellas, placemats, and multiple posters and signs attached to the railings.

\section{Discussion}

The motto of the Just For Laughs festival is "Laughter makes miracles". As a demonstration of this motto, the front cover of the festival programme features a young man who is initially unhappy because he has a pimple on his nose. However, he is smiling once this pimple has been transformed into a clown's nose. With pimples being something with which many youths identify strongly, as well as having a cartoon character on nearly all of the festival promotional materials, young people seem likely to identify with the promotional messages.

Tobacco consumption is responsible for a greater number of deaths among Canadians than the total caused by car accidents, suicides, murders, AIDS, and illicit drug use combined. Each year, approximately 45000 Canadians die prematurely as a result of tobacco use. ${ }^{10}$ Given the seriousness of the public health issue, the association of tobacco with carefree, lighthearted comedy seems both ironic and inappropriate.

The Supreme Court of Canada, in a five-tofour decision, ruled in 1995 that the Tobacco Products Control Act was unconstitutional. ${ }^{10}$ The replacement Tobacco Act was implemented in April 1997. Moreover, Bill C-42, which seeks to amend the Tobacco Act, and which received parliamentary first reading on 3 June 1998, proposes a five-year transition period before a total sponsorship ban is imposed in Canada. Canadian tobacco companies have evaded the intent of advertising provisions in the past through the sponsorship of cultural and sports events. The provisions of Bill C-42 aim to close some of the loopholes that were previously exploited by the tobacco companies.

Bill C-42, however, also contains some exploitable loopholes. For example, tobacco product advertisements are still permitted in the widely sold magazines that are imported into Canada, particularly from the United States. Furthermore, product placement (in film, television, or stage theatre) and internet advertising are not identified within the provisions of the Tobacco Act and Bill C-42.

Imperial Tobacco Ltd, RJR-Macdonald Inc., and Rothmans, Benson \& Hedges Inc. have already challenged the constitutionality of the Tobacco Act. The case will be heard by the Quebec Superior Court. ${ }^{11}$

TIMOTHY DEWHIRST
University of British Columbia, Green College,
6201 Cecil Green Park Road, Vancouver,
British Columbia V6T 1Z1, Canada;
tdewhirst@hotmail.com

Addendum tdewhirst@hotmail.com

Additional photographs from the Craven A Just For Laughs comedy festival can be found linked to the Physicians for a Smoke-free Canada web site at http://smoke-free.ca.

1 Woods R. Tobacco sponsorship advertising in the Ottawa/ Hull region. Ottawa: Canadian Council on Smoking and Health, 1993.

2 Canadian Tobacco Manufacturers' Council. A brief to the Legislative Committee of the House of Commons on Bill C-51. Ottawa, 1987

3 Canadian Tobacco Manufacturers' Council. Brief on Bill C-71 to the Standing Senate Committee on Legal and Constitutional Affairs. Ottawa, 1997.

4 Pollay RW. Export A ads are extremely expert, eh? Filter tips: a review of cigarette marketing in Canada. Physicians For A Smoke Free Canada, 1998, Autumn, vol 1. Published as an "E-zine" at <http://www.smoke-free.ca/filtertips_001/ Expert-eh.htm>.

5 Anon. Just For Laughs: the Montreal Comedy Festival, 31 August 1998. Online <www.hahaha.com/JPR/ANG/ histP0.html> [www.hahaha.com]

6 Radz M. Come fly with me: Andy Nulman's impossible dream. The Gazette 1998 Jul 25:C1,C3.

7 Hustak A. Last laugh goes to fest organizers. The Gazette 1998 Jul 28:A1.

8 Brownstein B. Acid-tongued Rickles leads the charge. The Gazette 1998 May 26:F7.

9 Lamey M. Just For Laughs festival attracts fans, agents, producers - and rain. The Gazette 1995 Jul 21:C1

10 Cunningham R. Smoke and mirrors: the Canadian tobacco war. Ottawa: International Development Research Centre, 1996.

11 Carey E. "Hurting" begins over tobacco ad crackdown. The Toronto Star 1997 Dec 8:A3. 